\title{
Hepatic damage during acute pancreatitis in the rat
}

\author{
A.M.M. Coelho', \\ M.C.C. Machado ${ }^{1}$, \\ S.N. Sampietre ${ }^{1}$, \\ K.R.M. Leite ${ }^{1}$, \\ V.L.L. Oliveira ${ }^{2}$ \\ and H.W. Pinotti ${ }^{1}$
}

\author{
${ }^{1}$ Laboratório de Cirurgia do Aparelho Digestivo-LIM35, \\ Departamento de Gastroenterologia, Hospital das Clínicas, Faculdade de Medicina, \\ Universidade de São Paulo, 05403-900 São Paulo, SP, Brasil \\ ${ }^{2}$ Unidade de Hipertensão, INCOR, Faculdade de Medicina, Universidade de São Paulo, \\ 05403-900 São Paulo, SP, Brasil
}

\section{Correspondence \\ M.C.C. Machado \\ Laboratório de Cirurgia do \\ Aparelho Digestivo-LIM35 \\ Hospital das Clínicas, FM, USP \\ Rua Dr. Enéas C. Aguiar, 255 \\ 05403-900 São Paulo, SP \\ Brasil}

Publication supported by FAPESP

Received October 1, 1996

Accepted June 30, 1997

\section{Abstract}

We studied the alterations in the metabolism of liver mitochondria in rats with acute pancreatitis. Male Wistar rats were allocated to a control group (group I) and to five other groups corresponding to 2, 4, 12,24 and $48 \mathrm{~h}$ after the induction of acute pancreatitis by the injection of $5 \%$ sodium taurocholate into the pancreatic duct. Sham-operated animals were submitted to the same surgical steps except for the induction of acute pancreatitis. Mitochondrial oxidation and phosphorylation were measured polarographically by determining oxygen consumption without ADP (basal respiration, state 4) and in the presence of ADP (activated respiration, state 3). Serum amylase, transaminases (ALT and AST) and protein were also determined. Ascitic fluid, contents of amylase, trypsin and total protein were also determined and arterial blood pressure was measured in all groups. In ascitic fluid, trypsin and amylase increased reaching a maximum at 2 and $4 \mathrm{~h}$, respectively. Serum amylase increased at $2 \mathrm{~h}$ reaching a maximum at $4 \mathrm{~h}$. Serum transaminase levels increased at 12 and $24 \mathrm{~h}$. After $2 \mathrm{~h}$ (and also $4 \mathrm{~h}$ ) there was an increase in state 4 respiration $(45.65 \pm 1.79 v s 28.96 \pm 1.50)$ and a decrease in respiration control rate $(3.53 \pm 0.09 v s 4.45 \pm 0.08)$ and in the ADP/O ratio $(1.77 \pm 0.02 v s 1.91$ $\pm 0.01)$ compared to controls $(\mathrm{P}<0.05)$. These results indicate a disruption of mitochondrial function, which recovered after $12 \mathrm{~h}$. In the 48 -h groups there was mitochondrial damage similar to that occurring in ischemic lesion. Beat-to-beat analysis (30 min) showed that arterial blood pressure remained normal up to $24 \mathrm{~h}(111 \pm 3$ $\mathrm{mmHg}$ ) while a significant decrease occurred in the 48-h group $(91 \pm$ $4 \mathrm{mmHg}$ ). These data suggest biphasic damage in mitochondrial function in acute pancreatitis: an initial uncoupled phase, possibly secondary to enzyme activity, followed by a temporary recovery and then a late and final dysfunction, associated with arterial hypotension, possibly related to ischemic damage.
Key words

- Acute pancreatitis

- Hepatic lesion

- Mitochondria

..................... 


\section{Introduction}

Acute pancreatitis is known to produce morphologic and functional changes in the liver and is associated with a high mortality rate (1-3). Many experimental studies suggest that hepatic cells can be injured during acute pancreatitis due to pancreatic enzymes or kinins expected to enter the portal system (4). It has been shown that the pancreatitisassociated ascitic fluid depresses rat liver cell oxygen uptake (5-7).

In an attempt to characterize these alterations, an experimental model was developed to investigate mitochondrial liver metabolism in rats with acute pancreatitis and the results were correlated with hemodynamic data, ascitic fluid composition and histological findings.

\section{Material and Methods}

Male Wistar rats weighing 220-270 g were used in all experiments. The animals were kept at $22-24^{\circ} \mathrm{C}$ on a 12 -h light-dark cycle, and fasted for $16 \mathrm{~h}$, with free access to water. Rats were allocated to a control group (without any operation) (group I, $\mathrm{N}=14$ ), and to one of five other (experimental) groups according to the time elapsed after acute pancreatitis (AP) induction: $2 \mathrm{~h}$ (group 2, $\mathrm{N}$ $=12$ ), $4 \mathrm{~h}$ (group 4, N =6), $12 \mathrm{~h}$ (group 12, $\mathrm{N}$ $=8$ ), $24 \mathrm{~h}$ (group $24, \mathrm{~N}=7$ ), and $48 \mathrm{~h}$ (group $48, \mathrm{~N}=7)$.

Acute pancreatitis was induced after laparotomy under ketamine chloride anesthesia $(0.2 \mathrm{ml} / 100 \mathrm{~g}$ body weight). The main pancreatic duct was cannulated transduodenally with a flexible catheter (Intracath, P50, Becton-Dickinson, Parsippany, NJ) and 0.5 $\mathrm{ml}$ of $5 \%$ sodium taurocholate in saline was infused at a constant rate. In order to direct the solution to the pancreatic duct a clamp was applied to the proximal part of the hepatic duct during injection $(8,9)$. Sham-operated groups were submitted to the same surgical steps as the experimental group except for the induction of acute pancreatitis and the animals were sacrificed 2, 4, 12, 24 and $48 \mathrm{~h}$ after the surgical procedure.

The animals were killed by a blow to the head followed by exsanguination. Blood samples were collected from animals of all groups to measure serum aspartate aminotransferase (AST), alanine aminotransferase (ALT) (Technicon RA-1000 System), amylase (10) and total protein (11). Ascitic fluid was removed from the abdominal cavity with a syringe and placed in glass vessels and the volume was determined. The contents of free active trypsin and total trypsin after activation of trypsinogen by enterokinase $(12,13)$, amylase and total protein were also determined.

Liver mitochondria were prepared as described in Ref. 7. Mitochondrial oxygen consumption was measured polarographically (14) using a Gilson 5/6H Oxygraph (Gilson Medical Electronics Inc., Middleton, WI) in a closed reaction vessel fitted with a Clark oxygen electrode (Yellow Springs Instruments Co., Yellow Springs, $\mathrm{OH})$ at $28^{\circ} \mathrm{C}$. The incubation medium consisted of 120 $\mathrm{mM} \mathrm{KCl}, 2 \mathrm{mM}$ sodium phosphate, $10 \mu \mathrm{M}$ rotenone, and $1 \mathrm{mM}$ EGTA, and was buffered at $\mathrm{pH} 7.1$ with $5 \mathrm{mM}$ Tris-HCl. Mitochondria were energized with potassium succinate as substrate at a final concentration of $10 \mathrm{mM}$. After a brief equilibration period, state 3 (activated state, S3) respiration was induced by the addition of $280 \mathrm{nmol}$ adenosine diphosphate (ADP, Sigma Chemical Co., St. Louis, MO). After all the added ADP was phosphorylated to adenosine triphosphate (ATP), state 4 (basal state, S4) respiration was measured. The ratio of oxygen consumption in the presence of ADP to that in its absence (respiratory control rate, RCR) and the ADP/O ratio were calculated as indices of oxidative and phosphorylative mitochondrial function (15). RCR = oxygen consumption in state 3/oxygen consumption in state 4.

$\mathrm{ADP} / \mathrm{O}=$ mol of ATP formed from ADP 
per atom of oxygen consumed. State 3 and state 4 respiratory rates are reported as nanogram atoms of oxygen per milligram mitochondrial protein per minute. Mitochondria protein content was determined by the method of Lowry et al. (11).

The femoral artery was cannulated $24 \mathrm{~h}$ before the induction of acute pancreatitis. Arterial blood pressure (ABP) was recorded in conscious, freely moving rats with the arterial cannula connected to a pressure transducer (Statham P23Db, Hato Rey, PR) coupled to an amplifier (General Purpose Stemtech Inc., Winston, VA). Pulsatile arterial pressure was sampled at $120 \mathrm{~Hz}$ under basal conditions and 2, 4, 24 and $48 \mathrm{~h}$ after AP with an analog-to-digital converter and processed with a computer on a beat-to-beat basis (AT-CODAS), providing values of mean arterial pressure.

Liver and pancreas from four rats in each group were fixed in $10 \%$ formaldehyde and embedded in paraffin, and 5-6- $\mu \mathrm{m}$ sections were stained with hematoxylin-eosin $(\mathrm{H}+\mathrm{E})$.

\section{Statistical analysis}

The results are reported as means $\pm \mathrm{SD}$. The significance of the differences between the mean values was evaluated by analysis of variance (ANOVA).

\section{Results}

\section{Blood and ascitic fluid}

The animals showed increased serum transaminase levels 12 and $24 \mathrm{~h}$ after induction of acute pancreatitis (Table 1). Serum amylase increased rapidly within the first 2 $\mathrm{h}$, reached a maximum at $4 \mathrm{~h}$, and then returned to basal levels at $48 \mathrm{~h}$. Total serum protein content decreased 12 and $24 \mathrm{~h}$ after the induction of pancreatitis.

Free active trypsin, total trypsin and amylase in the ascitic fluid reached a maximum 2 $\mathrm{h}$ ( $4 \mathrm{~h}$ for amylase) after the induction of acute pancreatitis and then decreased gradually. The protein levels increased 24 and 48 $\mathrm{h}$ after induction of AP. The largest volume of ascitic fluid was observed $12 \mathrm{~h}$ after the induction of pancreatitis (Table 2).

\section{Oxidation and phosphorylation of liver mitochondria}

Table 3 shows the results of liver mitochondrial function. After 2 and $4 \mathrm{~h}$ there was an increase in the oxygen consumption rate by liver mitochondria in $\mathrm{S} 3$ and $\mathrm{S} 4$, and a decrease in RCR and in the ADP/O ratio. At 12 and $24 \mathrm{~h}, \mathrm{RCR}$ increased to normal levels while the other parameters remained unchanged. After $48 \mathrm{~h}$ of acute pancreatitis a significant reduction in RCR, state 3 respiration and ADP/O ratio was observed.

\section{Arterial blood pressure}

Blood pressure remained within normal levels at $2 \mathrm{~h}$ and $4 \mathrm{~h}(111 \pm 3 \mathrm{mmHg})$ but significant hypotension was observed in all

Table 1 - Changes in serum alanine aminotransferase (ALT), aspartate aminotransferase (AST), amylase and total protein in experimental acute pancreatitis (AP).

Data are reported as means $\pm \mathrm{SD}$. ${ }^{*} \mathrm{P}<0.05$ compared to control (analysis of variance).

\begin{tabular}{|c|c|c|c|c|}
\hline & $\begin{array}{l}\text { ALT } \\
\text { (IU) }\end{array}$ & $\begin{array}{l}\text { AST } \\
\text { (IU) }\end{array}$ & $\begin{array}{c}\text { Amylase } \\
(\mathrm{U} / \mathrm{ml})\end{array}$ & $\begin{array}{c}\text { Total protein } \\
\text { (g\%) }\end{array}$ \\
\hline Control $(N=4)$ & $33 \pm 1$ & $153 \pm 10$ & $7.5 \pm 0.1$ & $8.2 \pm 0.2$ \\
\hline $\mathrm{AP} 2 \mathrm{~h}(\mathrm{~N}=8)$ & $48 \pm 4$ & $200 \pm$ & $17.1 \pm 1.9^{*}$ & $8.0 \pm 0.2$ \\
\hline SHAM 2 h $(N=3)$ & $43 \pm 3$ & $142 \pm$ & $7.8 \pm 0.1$ & $7.8 \pm 0.1$ \\
\hline AP 4 h $(N=5)$ & $68 \pm 3$ & $241 \pm$ & $29.7 \pm 1.3^{*}$ & $7.9 \pm 0.4$ \\
\hline SHAM 4 h $(N=2)$ & $44 \pm 8$ & $141 \pm 11$ & $7.6 \pm 0.1$ & $7.3 \pm 0.1$ \\
\hline AP $12 \mathrm{~h}(\mathrm{~N}=5)$ & $145 \pm 17^{*}$ & $472 \pm$ & $17.5 \pm 2.1^{*}$ & $6.7 \pm 0.2^{*}$ \\
\hline SHAM $12 \mathrm{~h}(\mathrm{~N}=2)$ & $68 \pm 2$ & $138 \pm$ & $9.1 \pm 0.1$ & $7.9 \pm 0.1$ \\
\hline AP $24 \mathrm{~h}(\mathrm{~N}=6)$ & $133 \pm 31^{*}$ & $590 \pm 110^{*}$ & $17.9 \pm 2.6^{*}$ & $6.2 \pm 0.2^{*}$ \\
\hline SHAM $24 \mathrm{~h}(\mathrm{~N}=2)$ & $67 \pm 8$ & $140 \pm 18$ & $8.8 \pm 0.2$ & $7.8 \pm 0.4$ \\
\hline AP $48 \mathrm{~h}(\mathrm{~N}=4)$ & $63 \pm 6$ & $177 \pm$ & $8.6 \pm 0.9$ & $7.7 \pm 0.3$ \\
\hline SHAM 48 h $(N=2)$ & $65 \pm 6$ & $165 \pm$ & $8.4 \pm 0.8$ & $7.7 \pm 0.4$ \\
\hline
\end{tabular}


animals at 24 and $48 \mathrm{~h}(91 \pm 4 \mathrm{mmHg})$ (Figure 1).

\section{Histological analysis}

Acute pancreatitis with acinar necrosis, hemorrhage and edema was observed in all animals. Sinusoidal liver congestion and slight inflammation were observed at 2, 4 and $12 \mathrm{~h}$. Necrosis and degenerative changes of hepatocytes were observed at 24 and $48 \mathrm{~h}$ (Figure 2).

\section{Discussion}

Hepatic dysfunction is associated with AP and has been described by many authors (1-3,16-25). Potent hepatotoxic substances have been found in the pancreatitis-associated ascitic fluid whose toxicity on isolated rat liver mitochondria function has been described (5-7). The effect on mitochondrial function was mainly due to uncoupling of oxidative phosphorylation. However, a slight enhancement of ATP synthesis in liver mito-

Table 2 - Analysis of pancreatitis-associated ascitic fluid in rats.

Data are reported as means $\pm \mathrm{SD}$. ${ }^{*} \mathrm{P}<0.05$ compared to other groups without asterisk; ${ }^{*} \mathrm{P}<0.05$ compared to $2,4,12,24 \mathrm{~h}$ (analysis of variance). $\mathrm{U} / \mathrm{ml}$ Trypsin $=\mu \mathrm{mol}$ of substrate released per $\mathrm{ml} \mathrm{per} \mathrm{min}$. $\mathrm{U} / \mathrm{ml}$ Amylase $=\mathrm{mg}$ of substrate released per min per $\mathrm{ml}$. AP $=$ Acute pancreatitis.

\begin{tabular}{|c|c|c|c|c|c|}
\hline & $\begin{array}{l}\text { Volume } \\
\text { (ml) }\end{array}$ & $\begin{array}{l}\text { Activated } \\
\text { trypsin } \\
\left(10^{-3} \mathrm{U} / \mathrm{ml}\right)\end{array}$ & $\begin{array}{c}\text { Total } \\
\text { trypsin } \\
\left(10^{-3} \mathrm{U} / \mathrm{ml}\right)\end{array}$ & $\begin{array}{c}\text { Amylase } \\
(\mathrm{U} / \mathrm{ml})\end{array}$ & $\begin{array}{c}\text { Total } \\
\text { protein } \\
(\mathrm{g} \%)\end{array}$ \\
\hline AP $2 \mathrm{~h}(\mathrm{~N}=7)$ & $3.9 \pm 0.3$ & $5.65 \pm 0.87^{*}$ & $42.38 \pm 9.1^{*}$ & $269 \pm 25^{*}$ & $3.2 \pm 0.2$ \\
\hline AP $4 \mathrm{~h}(\mathrm{~N}=5)$ & $4.4 \pm 1.3$ & $4.37 \pm 0.63^{*}$ & $29.22 \pm 5.0^{*}$ & $304 \pm 16^{*}$ & $2.0 \pm 0.2$ \\
\hline AP $12 \mathrm{~h}(\mathrm{~N}=6)$ & $9.6 \pm 3.4^{*}$ & $2.00 \pm 0.25$ & $4.77 \pm 0.7$ & $124 \pm 13$ & $3.0 \pm 0.2$ \\
\hline AP 24 h (N = 7) & $4.0 \pm 0.9$ & $0.95 \pm 0.21$ & $5.22 \pm 0.9$ & $81 \pm 16$ & $4.2 \pm 0.2^{*}$ \\
\hline AP 48 h $(N=5)$ & $2.4 \pm 0.9$ & $0.32 \pm 0.10$ & $2.27 \pm 0.8$ & $4 \pm 1 * *$ & $4.5 \pm 0.2^{*}$ \\
\hline
\end{tabular}

Table 3 - Oxidation and phosphorylation activities of mitochondria in experimental acute pancreatitis.

Data are reported as means $\pm \mathrm{SD}$. S3 and $\mathrm{S} 4=$ Oxygen consumption in ng atoms of $\mathrm{O}_{2} \mathrm{~min}^{-1} \mathrm{mg}$ protein $^{-1} ; \mathrm{RCR}=\mathrm{S} 3 / \mathrm{S} 4$. ${ }^{*} \mathrm{P}<0.05$ compared to control and sham groups (analysis of variance); ${ }^{*} \mathrm{P}<0.05$ compared to control, AP 2, 4, 12, $24 \mathrm{~h}$ and sham groups (analysis of variance).

\begin{tabular}{|c|c|c|c|c|}
\hline & $\mathrm{RCR}$ & S3 & S4 & ADP/O \\
\hline Control (N = 14) & $4.45 \pm 0.08$ & $127.84 \pm 5.81$ & $28.96 \pm 1.50$ & $1.91 \pm 0.01$ \\
\hline AP 2 h (N = 12) & $3.53 \pm 0.09 *$ & $160.10 \pm 5.57^{*}$ & $45.65 \pm 1.79 *$ & $1.77 \pm 0.02^{*}$ \\
\hline SHAM 2 h $(N=3)$ & $4.55 \pm 0.28$ & $120.71 \pm 9.25$ & $26.70 \pm 2.22$ & $1.95 \pm 0.02$ \\
\hline AP $4 \mathrm{~h}(\mathrm{~N}=6)$ & $3.51 \pm 0.19 *$ & $153.62 \pm 8.07^{*}$ & $44.45 \pm 3.30^{*}$ & $1.78 \pm 0.04^{*}$ \\
\hline SHAM 4 h $(\mathrm{N}=3)$ & $4.12 \pm 0.07$ & $119.90 \pm 4.54$ & $27.20 \pm 1.22$ & $1.91 \pm 0.03$ \\
\hline AP $12 \mathrm{~h}(\mathrm{~N}=8)$ & $4.26 \pm 0.05$ & $149.45 \pm 3.87^{*}$ & $35.12 \pm 0.87^{*}$ & $1.85 \pm 0.02^{*}$ \\
\hline SHAM 12 h $(\mathrm{N}=3)$ & $4.28 \pm 0.28$ & $106.50 \pm 5.63$ & $25.08 \pm 2.96$ & $1.90 \pm 0.01$ \\
\hline AP 24 h $(N=7)$ & $4.24 \pm 0.23$ & $144.77 \pm 8.38^{*}$ & $33.95 \pm 2.98^{*}$ & $1.77 \pm 0.02^{*}$ \\
\hline SHAM 24 h $(N=3)$ & $4.06 \pm 0.06$ & $117.67 \pm 0.78$ & $28.99 \pm 0.23$ & $1.94 \pm 0.03$ \\
\hline AP 48 h $(N=7)$ & $3.15 \pm 0.23^{*}$ & $84.99 \pm 8.98^{* *}$ & $26.50 \pm 1.58$ & $1.81 \pm 0.04^{*}$ \\
\hline SHAM 48 h $(N=2)$ & $4.19 \pm 0.16$ & $114.19 \pm 8.99$ & $27.65 \pm 1.48$ & $1.93 \pm 0.04$ \\
\hline
\end{tabular}


chondria $24 \mathrm{~h}$ after the induction of AP has been reported by others $(21,22)$. These investigators also observed a significant reduction in mitochondrial function over a period of 2 days after the induction of AP (21). However, the early periods of acute pancreatitis were not evaluated in these studies.

In the present study we observed increased levels of trypsin and amylase in the ascitic fluid in the early periods ( 2 and $4 \mathrm{~h}$ ) after induction of acute pancreatitis (Table 2), suggesting that systemic absorption of toxic substances from the ascitic fluid may occur early after induction of AP, causing liver damage.

Our results demonstrate disruption of mitochondrial function early after induction of acute pancreatitis (Table 3). In the early

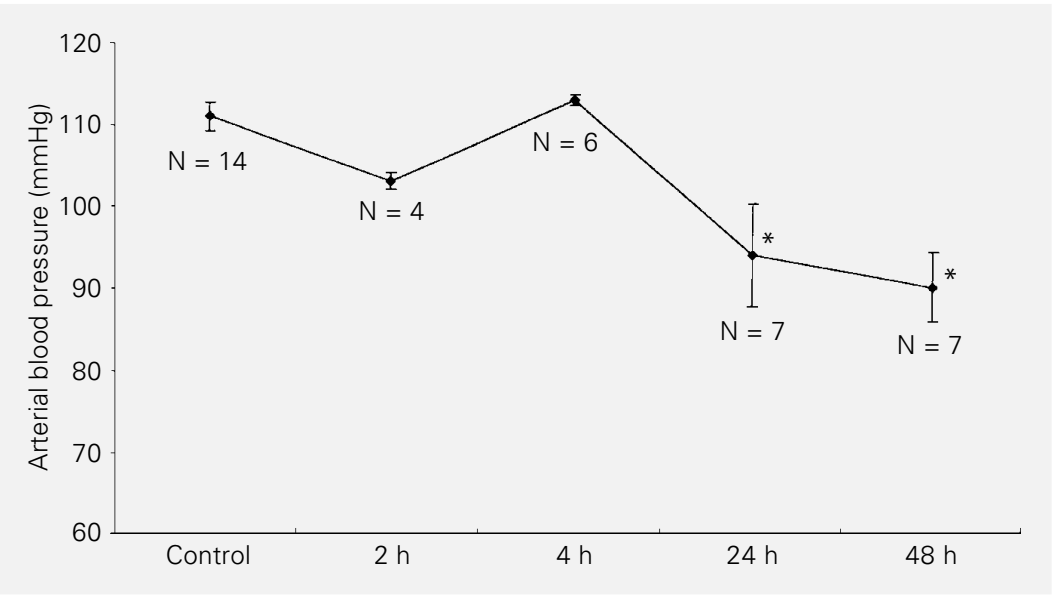

Figure 1 - Arterial blood pressure in acute experimental pancreatitis. Data reported as means \pm SD for $N$ animals in each group. ${ }^{*} \mathrm{P}<0.05$ compared to control (analysis of variance).

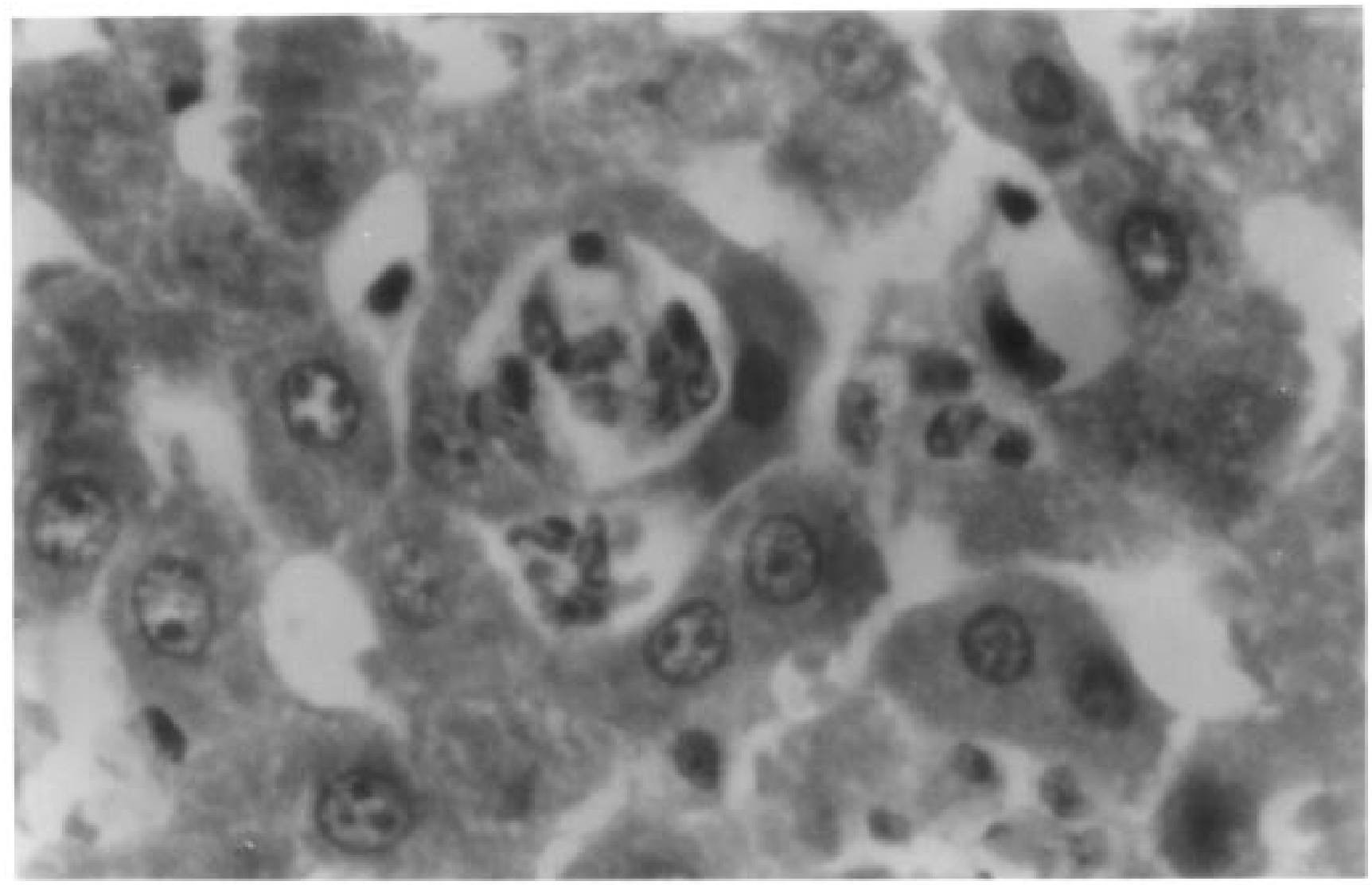

Figure 2 - Liver biopsy $48 \mathrm{~h}$ after induction of acute pancreatitis showing lobular focal necrosis and mononuclear inflammatory cell infiltrates. $\mathrm{H}+\mathrm{E}$. 400X. 
periods an uncoupling effect on mitochondrial function was observed, together with decreases in RCR, an increase in state 4 respiration and a reduction in the ADP/O ratio. In this early phase ( 2 and $4 \mathrm{~h}$ ) no significant changes in serum transaminases were observed (Table 1). After the 12-h period, however, an increasing depression of all parameters of mitochondrial respiratory functions with decreased mitochondrial ATP synthesis was observed. Since biological functions depend on a source of high energy phosphate, its decrease may cause severe damage to hepatic cells. Actually, after the 12-h period we observed increased levels of serum AST and ALT indicating hepatic cellular damage. At $48 \mathrm{~h}$ after induction of AP, a decrease in RCR, in state 3 respiration and in $\mathrm{ADP} / \mathrm{O}$ ratio was observed, suggesting a degenerative and necrotizing process characteristic of cellular ischemia (Table 3).

Kitamura et al. (21) also demonstrated significant damage to mitochondrial function $48 \mathrm{~h}$ after the induction of AP. In the present study, these alterations were associated with a decrease in arterial blood pressure (Figure 1) and are consistent with the results of previous studies demonstrating depressed liver mitochondrial respiratory function in response to shock and ischemia (26-28). Cell death may result from mitochondrial respiratory dysfunction.

Thus, the present findings demonstrate a biphasic damage to liver mitochondrial function in acute pancreatitis: an initial phase of uncoupling of oxidative phosphorylation and a late phase with damage to mitochondrial ATP synthesis. In the early phase of AP, the level of pancreatic enzymes in the ascitic fluid is high, suggesting that disruption of mitochondrial function during this period may be related to toxic substances released during this phase (5), followed by a temporary and partial recovery (Table 3 ). In the late phase, mitochondrial dysfunction is associated with arterial hypotension and probably related to ischemic damage.

Further studies are needed to elucidate the different factors involved in the pathophysiology of AP, in particular the abnormalities of liver mitochondrial function and to determine the appropriate treatment.

\section{Acknowledgment}

The authors are grateful to Prof. Dr. Eduardo Moacyr Krieger for assistance in the study of hemodynamic data. 


\section{References}

1. Fisher ER \& McCloy D (1955). Hepatic lesions of acute hemorrhagic pancreatitis. Surgery, 37: 213-219.

2. Anderson MC (1966). Hepatic morphology and function: alterations associated with acute pancreatitis. Archives of Surgery, 92: 664-671.

3. Tuzhilin SA, Polsky AE \& Dreiling DA (1975). Hepatic lesions in pancreatitis. Gastroenterology, 64: 108-114.

4. Hirano T, Manabe T \& Tobe T (1992). Impaired hepatic energy metabolism in acute pancreatitis: Protective effects of prostaglandin E2 and synthetic protease inhibitor ONO 3307. Journal of Surgical Research, 53: 238-244.

5. Pappas TN, Lesser MA, Ellison EC \& Carey LC (1982). Pancreatitis associated ascitic fluid: effect on oxygen consumption of liver cells. Proceedings of the Society for Experimental Biology and Medicine, 169: 438-444.

6. Coticchia JM, Lesser MA, Carey LC, Mayer AD \& McMahon MG (1986). Peritoneal fluid in acute pancreatitis blocks hepatic mitochondrial respiration. Surgery, 100: 850-856.

7. Bielecki JW, Dlugosz J, Pawlicka E \& Gabryelewicz A (1989). The effect of pancreatitis associated ascitic fluid on some functions of rat liver mitochondria. International Journal of Pancreatology, 5: 145156.

8. Lankisch PG, Koop H, Winckler K, Folsch VR \& Creutzfeld W (1977). Somatostatin therapy of acute experimental pancreatitis. Gut, 18: 713-716.

9. Storck G (1971). Fat necrosis in acute pancreatitis. Acta Chirurgica Scandinavica, 137 (Suppl 417): 1-36.

10. Jamieson $A D$, Pruitt $K M$ \& Caldwell $R C$ (1969). An improved amylase assay. Journal of Dental Research, 48: 483.
11. Lowry $\mathrm{OH}$, Rosebrough NJ, Farr AL \& Randall RJ (1951). Protein measurement with the Folin phenol reagent. Journal of Biological Chemistry, 193: 265-275.

12. Glazer G \& Steer ML (1977). Requirements for activation of trypsinogen and chymotrypsinogen in rabbit pancreatic juice. Analytical Biochemistry, 77: 130141.

13. Erlanger B, Kokowzky M \& Cohen W (1961). The preparation and properties of two chromogenic substrates of trypsin. Archives of Biochemistry and Biophysics, 95: 271-278.

14. Estabrook K (1964). Mitochondrial respiratory control and the polarographic measurement of ADP/O ratios. In: Estabrook RW \& Pullman ME (Editors), Methods in Enzymology. Academic Press, New York.

15. Chance B \& Williams GR (1955). A simple and rapid assay of oxidative phosphorylation. Nature, 175: 1120-1121.

16. Amundsen E, Ofstad E \& Hangen PO (1968). Experimental acute pancreatitis in dogs. I. Hypotensive effect induced by pancreatic exudate. Scandinavian Journal of Gastroenterology, 3: 659-664.

17. Butler MR (1973). Abnormalities of liver function in acute pancreatitis. Southern Medical Journal, 6: 700-702.

18. Traverso WL, Pullos TG \& Frey ChF (1983). Hemodynamic characterization of porcine hemorrhagic pancreatitis ascitic fluid. Journal of Surgical Research, 34: 254-262.

19. Ellison EC, Pappas TN, Johnson JA, Fabri PJ \& Carey LC (1981). Demonstration and characterization of hemoconcentration effect of ascitic fluid that accumulates during hemorrhagic pancreatitis. Journal of Surgical Research, 30: 241-248.

20. Frey ChF, Wong HN, Hicman D \& Pullos T (1982). Toxicity of hemorrhagic ascitic fluid associated with hemorrhagic pancreatitis. Archives of Surgery, 117: 401-404.
21. Kitamura O, Ozawa K \& Honjo I (1973). Alterations of liver metabolism associated with experimental acute pancreatitis. American Journal of Surgery, 126: 379382.

22. Lu-nan Y, Ozawa O \& Kobayashi N (1992). Changes in hepatic energy metabolism in experimental acute pancreatitis. Chinese Medical Journal, 105: 684-688.

23. Akopian LA, Gabriélian NA, Kanaian AS, Karalova EM \& Magakian IA (1994). The morphofunctional changes in the hepatocytes of rats with experimental acute pancreatitis. Tsitologiia, 36: 829-836.

24. Poplawski C, Dlugosz JW, Gabryelewicz A, Pawlicka E, Wroblewski E \& Adrzejewska A (1996). Hepatic mitochondrial and lysosomal alterations in acute experimental pancreatitis with ethanolic coetiology in rats. Digestive Diseases and Sciences, 41: 139-148.

25. Dlugosz JW, Poplawski C, Pawlicka E, Wroblewski E \& Gabryelewicz A (1996). The effect of tilsuprost on the liver mitochondria in taurocholate pancreatitis in rats with antecedent acute ethanol abuse. Life Sciences, 59: 1297-1306.

26. Mittnacht Jr S, Sherman SC \& Farber JL (1979). Reversal of ischemic mitochondrial dysfunction. Journal of Biological Chemistry, 254: 9871-9879.

27. Townsed MD, Yokun MD \& Fry DE (1987). Hepatic microsomal adenosine triphosphatase and mitochondrial function. Archives of Surgery, 122: 813-816.

28. Iwata S, Tanaka A \& Ozawa K (1992). Alterations in the proton ATPase activity of rat liver mitochondria after hemorrhagic shock. Journal of Laboratory and Clinical Medicine, 3: 420-427. 